Eulis Tanti Marlina et al/Animal Production. 21(1):43-48, 2019

Accredited by Kemenristek Dikti No 32a/E/KPT/2017. ISSN 1411-2027

\title{
The Effect of Addition Fermented Dairy-Waste Water Sludge by Aspergillus niger in Ration on Growth Performance and The Caecal Microbial of Broiler Chickens
}

\author{
Eulis Tanti Marlina ${ }^{1 *}$, Roostita Lobo Balia ${ }^{1}$ and Denny Widaya Lukman ${ }^{2}$ \\ 1)Faculty of Animal Science, Padjadjaran University, Bandung, Indonesia \\ 2) Veterinary Department , Bogor Agriculture University, Bogor, Indonesia \\ *Corresponding author email: eulis.tanti@unpad.ac.id
}

\begin{abstract}
Dairy Wastewater Sludge (DWS) is sediment from milk processing with a nutritional content fits for feedstuff. This experimental research investigated the nutritional value of DWS on the growth of broilers, and its specific impact on the development of microflora on broiler digestion. Tapioca by-product was used as DWS binder while Aspergillus niger fermentation was applied to improve nutritional content. The rate of fermented DWS addition in the ration was evaluated by measuring broilers' weight gain for 35 days and microflora qualities in the cecum by counting the number of non-pathogenic and pathogenic bacteria in the cecum at the end of the research. The research data were analyzed by ANOVA with Duncan's multiple range test. The results showed that supplementing $20 \%$ fermented DWS in rations resulted in the highest body weight gain and could suppress the growth of pathogenic bacteria (Salmonella spp., E. coli, and Enterobacteriaceae) in caecal. The ratio of non-pathogenic and pathogenic bacteria increased proportionally to the addition of fermented DWS levels in the ration. Microorganism activity in the caecum was reflected in varied caecum weight of broilers treated with different levels of fermented DWS. The condition illustrates the good health status of livestock so as to optimize the growth of broilers.
\end{abstract}

Keywords: dairy wastewater sludge, broiler, microflora, cecum

Abstrak. Dairy Wastewater Sludge (DWS) adalah sedimen dari pengolahan susu. Kandungan nutrisi DWS dapat digunakan sebagai bahan pakan. Efek nutrisi dalam DWS diuji pada pertumbuhan broiler serta dampak spesifik pengembangan microflora pada pencernaan. Metode penelitian yang digunakan adalah eksperimental. Tapioca by-Product (onggok) digunakan sebagai DWS Binder sementara fermentasi dengan Aspergillus niger dilakukan untuk meningkatkan kandungan nutrisi. Tingkat penambahan DWS yang difermentasi dalam ransum dievaluasi melalui pengukuran kenaikan berat badan selama 35 hari dan kualitas mikroflora di sekum dengan menghitung jumlah bakteri non-patogen dan patogen pada akhir periode penelitian. Data penelitian dianalisis menggunakan ANOVA dan uji lanjut yang digunakan adalah tes Duncan. Hasil penelitian menunjukkan bahwa penambahan 20\% DWS yang difermentasi dalam ransum menghasilkan kenaikan berat badan tertinggi dan dapat menekan pertumbuhan bakteri patogen (Salmonella spp., E. koli dan Enterobacteriaceae) di sekum. Rasio non patogen dan bakteri patogen meningkat secara proporsional untuk penambahan tingkat DWS yang difermentasi. Berat sekum dari Broiler dengan tingkat DWS yang difermentasi yang berbeda merupakan representasi aktivitas mikroorganisme di sekum. Kondisi ini bisa mengilustrasikan status kesehatan ternak yang baik sehingga dapat mengoptimalkan pertumbuhan broiler.

Kata kunci: dairy wastewater sludge, broiler, microflora, sekum

\section{Introduction}

Dairy wastewater solid (DWS) is a waste produced from milk processing industry after degradation process in the stabilization pond. DWS is a good source of single protein cells. Previous studies reported that the single cell proteins are potential animal feed ingredients (Zhao, 2012; Wang et al., 2013; Yunus et al.,
2015). DWS has a high nutritional value as a source of protein such as $34.98 \%$ crude protein, $4.1 \%$ lactose, $9.77 \%$ crude fiber, $11.04 \%$ crude fat, $2.33 \%$ calcium, and $1.05 \%$ phosphorus based on dry matter (Marlina, 2010).

Lactose in DWS positively affects chicken gut microflora to improve production 
Eulis Tanti Marlina et al/Animal Production. 21(1):43-48, 2019

Accredited by Kemenristek Dikti No 32a/E/KPT/2017. ISSN 1411-2027

performance. One contributing factor to the composition of chicken gastrointestinal microflora is feed ingredients (Pan and Yu., 2013; Pourabedin and Zhao., 2015; Kers et al., 2018). Growth of non-pathogenic bacteria, such as lactic acid bacteria in chicken's gastrointestinal tract can reduce pathogenic bacteria through organic acids formation by controlling the $\mathrm{pH}$ in digestive tract. Chickens have a low ability to produce lactose enzymes; therefore, the lactose is not digested but turned into organic acids in cecum and colon which subsequently reduce $\mathrm{pH}$ in digestive tract and protect against pathogenic bacteria (Meimandipour et al. 2009, El-Banna et al., 2010; Alloui and Szczurek, 2017).

The limiting factors in processing DWS include high moisture content $(95 \%)$ and the pathogenic bacteria. Pathogenic bacteria commonly found in waste are Salmonella, Shigella, E. coli, Streptococcus, Pseudomonas aeruginosa, Mycobacterium, Gland Iamblia (Romdhana et al., 2009; Tang, 2019). DWS is very susceptible to decay and therefore, reduce the quality of nutrients. One of the efforts to process DWS is to fermentation using Aspergillus niger - a fungus of Aspergillus genus that does not produce mycotoxins. Tapioca by-product (onggok) is added to bind water content in DWS and to provide carbohydrates source for Aspergilus niger.

We studied the effect of DWS fermented levels in the diet on broiler and caecal microbial population, and ratio of Lactobacillus spp., Enterobacteriaceae, Salmonella, and Escherichia coli.

\section{Materials and Methods}

\section{Preparation of chicken and rations}

This research used 120 day old chicks (DOC) final stock Cobb strain obtained from PT Charoen Pokphand Jaya Farm with $<10 \%$ coefficient of variation were administered. The feed ingredients consisted of yellow corn, fine bran, soybean meal, coconut cake, fish meal, $\mathrm{CaCO}_{3}$, coconut oil, top mix, and fermented DWS. Fermented DWS was made by mixing milk sludge with tapioca by-product (onggok) flour with a ratio of 70:30, then fermented with $6 \% A$. niger and incubated for 3 days. The ration was prepared with 3000 $\mathrm{kcal} / \mathrm{kg}$ metabolic energy and $22 \%$ crude protein (Daghir, 1995). The composition of the ration, feed substance and metabolizable energy of feed ingredients are presented in Table 1 and 2. The ration and vitamin-enriched drinking water were given ad libitum. Disease prevention was carried out by administering ND vaccines.

Table 1. Composition of research rations

\begin{tabular}{lcccccc}
\hline \multirow{2}{*}{ Feed Ingredients } & \multicolumn{7}{c}{ Level of fermented DWS in ration } \\
\cline { 2 - 7 } & 0 & 5 & 10 & 15 & 20 & 25 \\
& & & $\%$ & & & 12.50 \\
Fish meal & 12.50 & 12.50 & 12.50 & 12.50 & 12.50 \\
Fermented DWS & 0.00 & 5.00 & 10.00 & 15.00 & 20.00 & 25.00 \\
Soybean meal & 19.50 & 18.00 & 16.00 & 14.25 & 12.50 & 11.00 \\
Coconut cake & 4.00 & 4.00 & 4.00 & 3.75 & 3.00 & 2.50 \\
Yellow corn & 58.50 & 56.00 & 53.00 & 50.00 & 46.50 & 44.00 \\
Fine bran & 2.50 & 1.50 & 1.50 & 1.50 & 2.50 & 2.00 \\
Coconut oil & 1.50 & 1.50 & 1.50 & 1.50 & 1.50 & 1.50 \\
CaCO & 0.50 & 0.50 & 0.50 & 0.50 & 0.50 & 0.50 \\
Premix & 1.00 & 1.00 & 1.00 & 1.00 & 1.00 & 1.00 \\
\hline \multicolumn{1}{c}{ Total } & 100.00 & 100.00 & 100.00 & 100.00 & 100.00 & 100.00 \\
\hline
\end{tabular}

Note: DWS = dairy wastewater solid 
Eulis Tanti Marlina et al/Animal Production. 21(1):43-48, 2019

Accredited by Kemenristek Dikti No 32a/E/KPT/2017. ISSN 1411-2027

Table 2. Feed substances and metabolizable energy of broiler feed ingredients.

\begin{tabular}{|c|c|c|c|c|c|c|c|c|c|}
\hline $\begin{array}{c}\text { Feed } \\
\text { Ingredients }\end{array}$ & $\begin{array}{l}\text { Crude } \\
\text { Protein }\end{array}$ & $\begin{array}{l}\text { Crude } \\
\text { Lipid }\end{array}$ & $\begin{array}{l}\text { Crude } \\
\text { Fiber }\end{array}$ & $\mathrm{Ca}$ & $P$ & Lysine & Met. & Cystine & ME \\
\hline & & $\ldots \ldots \ldots$ & .......... & .......... & $\%$ & .......... & ......... & ............ & $\mathrm{Kcal} / \mathrm{kg}$ \\
\hline Fish meal & 58.00 & 9.00 & 1.00 & 7.70 & 3.90 & 6.50 & 1.80 & 0.94 & 2970 \\
\hline $\begin{array}{l}\text { Fermented } \\
\text { DWS }\end{array}$ & 21.76 & 3.42 & 6.64 & 0.96 & 0.76 & 0.81 & 0.19 & 0.30 & 3042 \\
\hline Soybean & 44.00 & 0.90 & 6.00 & 0.32 & 0.29 & 2.90 & 0.65 & 0.67 & 2240 \\
\hline meal & 21.00 & 1.80 & 15.00 & 0.20 & 0.20 & 0.64 & 0.29 & 0.30 & 1540 \\
\hline Coconut cake & 8.60 & 3.90 & 2.00 & 0.02 & 0.10 & 0.20 & 0.18 & 0.18 & 3370 \\
\hline Yellow corn & 12.00 & 13.00 & 12.00 & 0.12 & 0.21 & 0.77 & 0.29 & 0.40 & 1630 \\
\hline Fine bran & 0.00 & 100.00 & 0.00 & 0.00 & 0.00 & 0.00 & 0.00 & 0.00 & 8600 \\
\hline Coconut oil & 0.00 & 0.00 & 0.00 & 40.00 & 0.00 & 0.00 & 0.00 & 0.00 & 0.00 \\
\hline $\mathrm{CaCO}_{3}$ & 0.00 & 0.00 & 0.00 & 24.00 & 12.00 & 0.00 & 0.00 & 0.00 & 0.00 \\
\hline $\begin{array}{l}\text { Bone meal } \\
\text { Premix }\end{array}$ & 0.00 & 0.00 & 0.00 & 0.00 & 0.00 & 0.30 & 0.30 & 0.00 & 0.00 \\
\hline
\end{tabular}

\section{Collections of sample and data}

The broiler chickens were placed in 24 litter cages ( 5 each) measuring $1 \times 0.5 \times 0.75 \mathrm{~m}$. The cage was equipped with a feeder, drinker, thermometers, hygrometers, heating and lighting equipment, and sanitary equipment.

Body weight was measured weekly using a 5-kg analytical scale with $1 \mathrm{~g}$ accuracy. Body weight gain was obtained from the discrepancy between final and initial body weight. The chickens were slaughtered at the end of the research. The cecum was cut, weighed, extracted in $1 \%$ physiological $\mathrm{NaCl}$ solution then frozen to be analyzed. The device for bacteria analysis were petri dishes, glass, osse, and micro objects.

\section{Microbial quality measurement in cecum}

Microbial quality in cecum was measured by calculating microflora population in cecum: Lactobacillus sp, Salmonella $s p$, E. coli, and Enterobacteriacae bacteria using a total plate count method. Different media for analysis included Violet Red Bile Glucose Agar/VRBGA for Enterobacteriaceae, Mc Conkey Agar for Salmonella $s p$ and E. coli, and MRS/de Man Rogosa Sharpe for Lactobacillus sp. Samples that had been diluted to $10^{9}$ were cultured in each medium, then incubated for 24 - 48 hours until colonies form. Total colonies calculated was total microbial cells per gram of sample
(Kornacki et al., 2013; APHA, 2012). Broiler's cecum was weighed during evisceration to determine microbial activity.

\section{Research design and data analysis}

The experimental study was conducted in a completely randomized design (CRD) with six ration treatments and four replicates. The treatments were the level of fermented DWS supplied into the ration, namely $0,5,10,15$, 20 , and $25 \%$. Data were subject to ANOVA, followed by Duncan's test for discrepancies identified across treatments.

\section{Results and Discussions}

Broiler body weight gain is presented in Table 3. Statistical analysis result showed that the level of fermented products did not significantly affect broiler body weight gain. The effect of $25 \%$ fermented DWS on body weight gain was similar to that of control ration. This is due to the improvement of nutritional quality in fermented DWS; therefore, that the nutritional value in the ration can be increased (Marlina, 2010). supplementing fermented DWS up to $25 \%$ could provide adequate sources of nutrition for broilers' growth and performance. It is evident that broilers' body weight gain in each treatment was between 1371.7 and 1491.1 $\mathrm{g} /$ head (Table 3). 
Eulis Tanti Marlina et al/Animal Production. 21(1):43-48, 2019

Accredited by Kemenristek Dikti No 32a/E/KPT/2017. ISSN 1411-2027

Table 3. Feed substances and metabolizable energy

\begin{tabular}{lccccccc}
\hline \multirow{2}{*}{ Nutrients } & \multicolumn{7}{c}{ Level of fermented DWS in rations } \\
\cline { 2 - 8 } & 0 & 5 & 10 & 15 & 20 & 25 & Requirement $^{*}$ \\
\hline Crude protein (\%) & 22.00 & 22.09 & 22.04 & 22.05 & 22.03 & 22.08 & 22.00 \\
Crude fat (\%) & 5.48 & 5.41 & 5.45 & 5.48 & 5.61 & 5.60 & $5.00-6.00$ \\
Crude fiber (\%) & 3.37 & 3.44 & 3.59 & 3.72 & 3.88 & 3.94 & $\leq 8.00$ \\
Lactose (\%) & - & 1.04 & 1.16 & 1.25 & 1.42 & 1.85 & \\
Calsium (\%) & 1.25 & 1.29 & 1.33 & 1.37 & 1.21 & 1.45 & $1.10-1.20$ \\
Phosphor (\%) & 0.62 & 0.64 & 0.67 & 0.70 & 0.73 & 0.76 & $0.60-0.90$ \\
Lysine (\%) & 1.54 & 1.53 & 1.50 & 1.48 & 1.47 & 1.46 & $0.90-1.10$ \\
Methyonine (\%) & 0.48 & 0.47 & 0.46 & 0.45 & 0.45 & 0.44 & 0.40 \\
Methyonine + cystine (\%) & 0.85 & 0.84 & 0.82 & 0.81 & 0.80 & 0.80 & $0.70-0.86$ \\
ME (Kcal/kg) & 2997 & 2980 & 2993 & 2995 & 3035 & 3054 & 3000 \\
\hline Note : *Daghir (1995) & & & & & & & 3000
\end{tabular}

Table 4. Body weight gain and cecum weight in broiler with addition of dairy waste water sludge and tapioca by-product (onggok) flour mixture

\begin{tabular}{lccccccc}
\hline \multirow{2}{*}{ Parameter } & Treatment & \multicolumn{9}{c}{ Replication } & Total & \multirow{2}{*}{ Mean } \\
\cline { 2 - 6 } & & \multicolumn{5}{c}{2} & \multicolumn{3}{c}{3} & 4 & \\
\hline \multirow{2}{*}{ Body weight } & $\mathrm{R}_{0}$ & 1366.30 & 1426.40 & 1306.20 & 1388.00 & 5486.90 & $1371.73 \pm 50.26$ \\
gain & $\mathrm{R}_{1}$ & 1482.80 & 1547.40 & 1413.40 & 1260.00 & 5703.60 & $1425.90 \pm 123.39$ \\
& $\mathrm{R}_{2}$ & 1502.20 & 1476.00 & 1420.20 & 1467.40 & 5865.80 & $1466.45 \pm 34.20$ \\
& $\mathrm{R}_{3}$ & 1409.80 & 1497.80 & 1523.60 & 1522.00 & 5953.20 & $1488.30 \pm 53.65$ \\
& $\mathrm{R}_{4}$ & 1547.60 & 1541.00 & 1469.50 & 1406.20 & 5964.30 & $1491.08 \pm 66.73$ \\
& $\mathrm{R}_{5}$ & 1465.40 & 1522.60 & 1531.00 & 1436.40 & 5955.40 & $1488.85 \pm 45.52$ \\
\hline Cecum & $\mathrm{R}_{0}$ & 3.54 & 3.82 & 3.57 & 2.91 & 13.84 & $3.46 \pm 0.39^{\mathrm{a}}$ \\
weight & $\mathrm{R}_{1}$ & 3.91 & 4.84 & 4.96 & 5.91 & 19.62 & $4.91 \pm 0.82^{\mathrm{b}}$ \\
& $\mathrm{R}_{2}$ & 5.22 & 5.02 & 4.69 & 4.11 & 19.04 & $4.76 \pm 0.49^{\mathrm{b}}$ \\
& $\mathrm{R}_{3}$ & 5.76 & 5.35 & 4.90 & 5.54 & 21.55 & $5.39 \pm 0.37^{\mathrm{b}}$ \\
& $\mathrm{R}_{4}$ & 7.03 & 6.67 & 6.17 & 5.44 & 25.31 & $6.33 \pm 0.69^{\mathrm{c}}$ \\
& $\mathrm{R}_{5}$ & 6.43 & 5.45 & 6.71 & 6.96 & 25.55 & $6.39 \pm 0.66^{\mathrm{c}}$ \\
\hline
\end{tabular}

Note: $\quad R_{0}=$ Ration with $0 \%$ fermented DWS; $R_{1}=$ Ration with $5 \%$ fermented DWS; $R_{2}=$ Ration with $10 \%$ fermented DWS; $R_{3}=$ Ration with $15 \%$ fermented DWS; $R_{4}=$ Ration with $20 \%$ fermented DWS; $R_{5}=$ Ration with $25 \%$ fermented DWS, Different letter in each coloumn indicate difference between treatment, according Duncan's test $(P<0,05)$

The quality of cecum microflora was measured based on the ratio of the number of non-pathogenic bacteria (Lactobacillus spp) and pathogens (Salmonella sp, Escherichia coli and Enterobacteriaceae). The number of nonpathogenic bacteria reflected better health status (Patterson and Burkholder, 2003; Haque and Haque, 2017). The results showed discrepancies in the colonies and balance of lactic acid bacteria (Lactobacillus $s p$ ) against pathogenic bacteria such as Salmonella $s p$, Escherichia coli and Enterobacteriacea sp. in each treatment (Table 4). Lactose fermentation in the cecum will produce lactic acid which reduces $\mathrm{pH}$ in the cecum. Pathogenic bacteria, as reflected in this study, are generally intolerant to low $\mathrm{pH}$. Supplementing 25\% fermented DWS resulted in a lower cecum bacteria population (E. coli, Salmonella, and Enterobacteriaceae) than the control (higher Lactobacillus population).

This results in a greater balance of nonpathogenic bacteria with pathogenic bacteria with increasing fermented DWS in the ration. Salmonella was non-existent in the cecum of broilers receiving $15 \%$ fermented DWS (R2) to $25 \%$ level (R5). Lactose in DWS positively affects chickens. As lactase enzymes is nonexistent in chicken, lactose cannot be digested but passed to the cecum and colon to provide nutrient for lactic acid bacteria growth in 
Eulis Tanti Marlina et al/Animal Production. 21(1):43-48, 2019

Accredited by Kemenristek Dikti No 32a/E/KPT/2017. ISSN 1411-2027

Table 5. Cecum microflora with addition of dairy waste water sludge and tapioca by-product (onggok) flour in rations

\begin{tabular}{|c|c|c|c|c|c|c|}
\hline \multirow{2}{*}{ Bacteria } & \multicolumn{6}{|c|}{ Treatment } \\
\hline & $\mathrm{R}_{0}$ & $\mathrm{R}_{1}$ & $\mathrm{R}_{2}$ & $\mathrm{R}_{3}$ & $\mathrm{R}_{4}$ & $\mathrm{R}_{5}$ \\
\hline \multicolumn{7}{|c|}{ 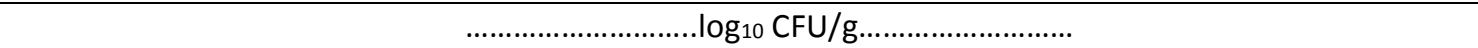 } \\
\hline Lactobacillus spp. & 9.00 & 9.04 & 9.20 & 9.23 & 9.38 & 9.40 \\
\hline Salmonella & 2.64 & 2.23 & nd & nd & nd & $\mathrm{Nd}$ \\
\hline Escherichia coli & 3.53 & 3.49 & 3.38 & 3.04 & 3.04 & 3.00 \\
\hline Enterobacteriaceae & 3.82 & 3.62 & 3.60 & 3.43 & 3.36 & 3.00 \\
\hline $\mathrm{L}: \mathrm{S}$ ratio & 3.40 & 4.05 & $\approx$ & $\approx$ & $\approx$ & $\approx$ \\
\hline L:E ratio & 2.55 & 2.59 & 2.72 & 3.03 & 3.08 & 3.13 \\
\hline L:En ratio & 2.36 & 2.50 & 2.56 & 2.69 & 2.79 & 3.13 \\
\hline
\end{tabular}

Note: $\quad$ nd $=$ non detected, $\approx$ infinite, $R_{0}=$ Ration with $0 \%$ fermented DWS; $R_{1}=$ Ration with $5 \%$ fermented DWS; $R_{2}=$ Ration with $10 \%$ fermented DWS; $R_{3}=$ Ration with $15 \%$ fermented DWS; $R_{4}=$ Ration with $20 \%$ fermented DWS; $R_{5}=$ Ration with $25 \%$ fermented DWS

cecum. Similarly, prebiotics is indigestible food ingredient but beneficial for their hosts by selectively stimulating the growth and activity of one or more bacteria in the large intestine (Dankowiakowska et al., 2013; Wilson Tang et al., 2019). Lactose as a probiotic for broilers is reflected in the growth of lactic acid bacteria in the cecum and the elimination of pathogenic bacteria such as E. coli, Salmonella, and Enterobacteriaceae. The high number of Lactobacillus $\mathrm{sp}$ in the cecum can produce a $\mathrm{pH}$ that is not conducive for the growth of pathogenic bacteria (Table 5).

\section{Conclusion}

Fermented DWS up to $25 \%$ in the ration resulted in a favorable condition for the growth of non-pathogenic microflora (Lactobacillus sp.) and inhibited the growth of pathogenic bacteria (Salmonella sp., Echerichia coli and Enterobacteriaceae) in the cecum of broiler chickens. It promoted health status which may optimize broilers' growth.

\section{References}

Alloui, MN and W Szczurek. 2017. Effect of different dietary levels of whey lactose as a prebioyic disaccharide on the productive performances and selected indices of the caecal micro-environment in broiler chickens. Ann. Anim. Sci. 17(4):1107-1122.

APHA, 2012. Standard Methods for the
Examination of water and waste water. $22^{\text {nd }}$ Eds., American Public Health Association, American Water Works Association, Water Environment Federation.

Daghir, NJ. 1995. Poultry Production in Hot Climate. At The University Press, Cambridge.

Dankowiakowska, A., I. Kozlowska, and M. Bednarczyk. 2013. Probiotics, Prebiotics and Synbiotics in Poultry-Mode of Action, Limitation, and Achievements. Journal of Central European Agriculture. 14(1):467-478.

El-Banna, HA, HY El-Zorba, TA Attia, and AA Elatif. 2010. Effect of probiotic, prebiotic and symbiotic on broiler performance. World Applied Sciences Journal. 11 (4): 388-393 ref.24.

Haque, SZ and M Haque. 2017. The ecological community of commensal, symbiotic, and pathogenic gastrointestinal microorganisms an appraisal. Clin Exp Gastroenterol. 10:91103.

Kermanshahi and Rostami. 2006. Influence of Supplemental Dried Whey on Broiler Performance and Cecal Flora. Poultry Science 5(6):538-543.

Kers, JG, FC Velkers, EAJ Fischer, GDA Hermes, JA Stegeman, and H Smidt. 2018. Host and Environmental factors affecting the intestinal microbiota in chickens. Front Microbiol. 9(235):1-14.

Kornacki, JL, JB Gurtler, and BA Stawick. 2013. Enterobacteriaceae, Coliforms, and Escherichia coli as Quality and Safety Indicators. In: Compendium of Methods for the Microbiological Examination of Foods. $5^{\text {th }}$ edition, American Public Health Association.

Laird, DT, SA Gambrel-Lenarz, FM Scher, TE Graham, and RRLJ Maturin. 2012. In: Standard methods for the examination of dairy products. American Public Health Association, 
Eulis Tanti Marlina et al/Animal Production. 21(1):43-48, 2019

Accredited by Kemenristek Dikti No 32a/E/KPT/2017. ISSN 1411-2027

Washington, DC.

Marlina, 2010. Biokonversi Limbah Industri Peternakan. Unpad Press, Bandung. 133-142.

Meimandipour, A, M Shuhaimi, M Hair-Bejo, $\mathrm{K}$ Azhar, BM Kabeir, B Rasti, and AM Yazid. 2009. In vitro fermentation of broiler cecal content: the role of lactobacilli and $\mathrm{pH}$ value on the composition of microbiota and end products fermentation. The Society for Applied Microbiology. 49: 415-420.

Pan, D and Z Yu. 2013. Intestinal microbiome of poultry and Its interaction with host and diet. Gut Microbes, 5(1):108-119.

Patterson, JA and KM Burkholder. 2003. Application of prebiotics and probiotics in poultry production. Poultry Science. 82(4):627-631.

Pourabedin, $M$ and $X$ Zhao. 2015. Prebiotics and gut microbiota in chickens. FEMS Microbiology Letters. Vol. 362. P. 18.Statistical Product and Service Solutions 17. 2010. SPSS for windows. SPSS Incorporation, New York, USA.

Romdhana, MH, D Lecomte, B Ladevie, and C Sablayrolles. 2009. Monitoring of pathogenic microorganisms contamination during heat drying process of sewage sludge. Process Safety and Environmental Protection. 87:377386.

SPSS Statistics. 2015. Statistical Package for the Scocial Sciences. SPSS Inc.

Szczurek, W, MN Alloui, and D Jozefiak. 2018. The effect of dietary whey lactose and lactobacillus agilis bacteria on the growth performance, physicochemical, conditions of the digestive tract and the caecal microbial

ecology of broiler chickens. Ann. Anim. Sci. 18(2): 483-500.

Tang, F, P. Zhang, Q. Zhang, F.Xue, J. Ren, J. Sun, Z. Qu, X. Zhuge, D. Li, J. Wang, M. Jiang, J. Dai. 2019. Isolation and Characterization of a broad-spectrum phage of multiple drug resistant Salmonella and its therapeutic utility inmice. Microb. Phatog., 126(2019):193-198.

Vicente, J, A Wolffenden, A Torres-Rodriguez, $S$ Higgins, G Tellez, and B Hargis. 2007. Effect of Lactobacillus species-based probiotic and dietary lactose prebiotic on Turkey poult performance with or without Salmonella Enteritidis challenge. J. Appl. Poult. Res. 16:361-364.

Wang, JP, JD Kim, JE Kim, and IH Kim. 2013. Amino acid digestibility of single cell protein from Corynebacterium ammoniagenes in growing pigs. Animal Feed Science and Technology. 180 (4):111-114.

Wilson Tang, W.H., F.Bacckhed, U. Landmesser, S.L. Hazen. 2019. Intestinal Microbiota in Cardiovascular Health and Disease: JACC State-of-the-Art Review. Journal of American College of Cardiology. 73(16):2089-2105.

Yunus, FUN, M Nadeem, and F Rashid. 2015. Single-cell protein production through microbial conversion of lignocellulosic residue (wheat bran) for animal feed. Journal of the Institute of Brewing. 121 (4):457-648.

Zhao, Y, B Yu, X Mao, J He, Z Huang, Q Mao, and D Chen. 2012. Effect of dietary bacterial lysine by-product meal supplementation on growth performance and excretion of purine base derivatives in growing-finishing pigs. Livestock Science. 149 (2):18-24. 